\title{
Studies on Lactic Acid Bacteria Isolate Sr 13 From Bali Cattle Gastric
}

\author{
Bagus Nanda Govinda Muria Siddhi ${ }^{1 *}$, I WayanSuardana ${ }^{2}$, Nyoman Semadi Antara $^{3}$, \\ ${ }^{1}$ Student, Faculty of Veterinary Medicine; ${ }^{2}$ Laboratory of Veterinary Public Health, Faculty \\ of Veterinary Medicine; ${ }^{3}$ Clinical Microbiology Laboratory, Faculty of Medicine, \\ Udayana University, Bali \\ *Corresponding Author: bagusnandagovinda@gmail.com
}

\begin{abstract}
Lactic acid bacteria (LAB) is a generic term for bacteria that ferment lactose and produce lactic acid as its main product. In general, lactic acid bacteria belonging to Gram positive bacteria, negative catalase, does not form spores, have no cytochrome, aerotolerant, anaerobic to microaerophilic, require complex nutrients such as amino acids, vitamins (B1, B6, B12 and biotin), purine, pyrimidine. This study aims to determine the species of lactic acid bacteria (LAB) from isolate SR13 isolated from rumen liquid of bali cattle. The identification was started by cultivation of isolate on de Man, Rogosa, Sharpe (MRS) medium with anaerobic condition, confirmation of isolates by Gram staining and catalase test, and finally identificion of species by using conventional test and 50CH API test kit. The results of study showed, the isolate of LAB SR 13 was detected asPediococcus/Enterococcus, moreover, identification by using 50CH Api test kit showed as Pediococcus pentosaceus 2.
\end{abstract}

\section{Keyword: Bali cattle, lacticacidbacteria SR13, identification}

\section{INTRODUCTION}

Lactic acid bacteria (BAL) are bacteria that are able to ferment sugar or carbohydrates to produce lactic acid. These bacteria are often found in various habitats such as fermented foods, fruits, and the digestive tract of humans or livestock [1]. Lactic acid bacteria (BAL) is one of the bacteria that has an important role in maintaining the balance of the digestive system ecosystem [2]. In general, lactic acid bacteria are classified as Gram positive bacteria, negative catalase, not spore forming, have no cytochrome, aerotolerant, anaerobic to microaerophilic, require complex nutrients such as amino acids, vitamins (B1, B6, B12, and biotin), purines, pyrimidine [2][3].

The digestive tract is the place where many microorganisms, both animals and humans, are contained. Ruminant animals such as cattle, goats and sheep as herbivores have rumen organs which act as digestive sites for cellulose and polysaccharides from plants with the help of certain microorganisms. The rumen contents are slaughterhouse waste from ruminants. Rumen fluid contains various microorganisms, both bacteria, fungi and protozoa. Rumen liquid is also potentially used as an inoculant rich in soluble nutrients, microbes and fiber degrading enzymes. Rumen is an ideal place for the development of bacteria - anaerobic group including lactic acid bacteria, due to a fixed rumen temperature (390C), with $\mathrm{pH}$ (6.5) and naturally anaerobic (E0 $=-0.4$ volts).

Bali cattle (Bossondaicus) are native to Bali island that have the advantage of being able to adapt to unfavorable environments, can adapt to simple types of feed and have a high digestibility to feed with high fiber content [4]. Considering that the rumen of bali cattle contains 
various types of bacteria which can be further utilized, it is deemed necessary to isolate the bacteria found in the rumen fluid of bali cattle.

\section{MATERIALS AND METHODS}

\section{Cultivation of Isolate BAL SR 13}

Cultivation of BAL isolate SR13 was carried out by reculture isolates by Gram staining

Gram staining on BAL isolates SR13 was done by coloring preparations which had been fixed using $2 \%$ crystal violet, left for 1 minute 30 seconds then washed with running water, then dripped with lugol liquid and left for 1 minute 30 seconds. Washed again with running water, then dripped with acetone alcohol and left for 30 seconds, then washed with running water. Then it was stained with safranin for 1 minute 30 seconds, then washed again with running water. The staining results can be seen under a microscope with 1000x magnification.

Catalase Test

Catalase test is performed to determine the presence of catalase enzyme activity. On object glass, add $10 \mu 1$ of BAL SR13 isolate then add one drop of $\mathrm{H} 2 \mathrm{O} 2$ $10 \%$. Observed the presence or absence of oxygen bubbles.

\section{Characterization of Isolates SR 13}

Characterization of SR 13 isolates was carried out to determine the ability of these isolates to grow at low temperatures $\left(10^{\circ} \mathrm{C}\right)$, high salinity $(15 \% \mathrm{NaCl})$, and in alkali media ( $\mathrm{pH}$ 9.6).

\section{Growing Capability at Low Temperatures}

taking BAL isolate SR13 using $20 \mu$ ll of micropipette, then put it in a $5 \mathrm{ml}$ MRS broth tube. Furthermore, the tube containing the culture was incubated at 370C for 24 hours in an anaerobic atmosphere. The success of reculture isolates was characterized by turbidity on MRS broth media.

A temperature test of $10^{\circ} \mathrm{C}$ was carried out to prove whether the bacteria were able to grow at low temperatures or not. Make MRS broth media as many as 7 tubes. Cultivation of BAL isolates SR13 was done by reculture isolates by taking BAL isolates SR13, then put into 6 tubes containing $5 \mathrm{ml}$ of MRS broth media as much as $10 \mu \mathrm{l}$ each. The 5 MRS broth tubes that have been planted with BAL were put into a refrigerator with a temperature of $10^{\circ} \mathrm{C}$, along with $1 \mathrm{MRS}$ broth media tube that was not planted with BAL. While the remaining 1 tube (which has been embedded with BAL) is incubated at $37^{\circ} \mathrm{C}$. Let stand for 24 hours then observe whether or not BAL grows based on the level of turbidity that occurs.

SR 13 Isolate Ability to Grow on High Salt Levels

A $15 \% \mathrm{NaCl}$ test was carried out to prove whether the bacteria were able to grow at high salinity or not. Make $15 \%$ $\mathrm{NaCl}$ media as many as 5 tubes and physiological $\mathrm{NaCl}$ as many as 2 tubes. Cultivation of BAL isolates SR13 was done by reculture isolates by taking $\mathrm{BAL}$ isolate SR13, then put it into 5 tubes containing $5 \mathrm{ml}$ of $15 \% \mathrm{NaCl}$ media and 1 tube of physiological $\mathrm{NaCl}$ of $10 \mu \mathrm{l}$ each. 5 of the $15 \% \mathrm{NaCl}$ tubes that have been planted by BAL were put into an incubator with a temperature of $37^{\circ} \mathrm{C}$, together with 
1 physiological $\mathrm{NaCl}$ tube that was not planted with BAL as a negative control. And 1 physiological $\mathrm{NaCl}$ tube that has been embedded with BAL as a positive control. Let stand for 24 hours then observe whether or not BAL grows based on the level of turbidity that occurs.

The ability of SR 13 Isolates to Grow in Alkaline Media

A pH 9.6 media test is carried out to prove whether bacteria are able to grow in alkaline conditions or not. Make MRS broth media pH 9.6 as many as 5 tubes and MRS broth without $\mathrm{pH}$ treatment as much as 2 tubes. Reculture BAL isolate SR13 by inserting BAL isolate SR13 into 5 tubes containing $5 \mathrm{ml}$ MRS broth $\mathrm{pH} 9.6$ and 1 MRS broth tube without $\mathrm{pH}$ treatment of $10 \mu \mathrm{l}$ each. The $5 \mathrm{MRS}$ broth tubes that had been planted with BAL were put into an incubator with a temperature of $37^{\circ} \mathrm{C}$, together with 1 MRS broth tube without $\mathrm{pH}$ treatment which was not planted with BAL as a negative control and 1 MRS broth tube without $\mathrm{pH}$ treatment which BAL had embedded as a positive control. Let stand for 24 hours then observe whether or not BAL grows based on the level of turbidity that occurs.

\section{Identification of Isolates SR 13}

The API 50CH kit test is carried out to identify bacterial species by utilizing the properties of lactic acid bacteria which ferment sugar. The first thing that was done was to homogenize bacterial isolates with vortex, then centrifuged at $7000 \mathrm{rpm}$ for 10 minutes. After being centrifuged, the supernatant was removed, and $5 \mathrm{ml}$ of sterile saline was added, vortex once again at $7000 \mathrm{rpm}$ for 10 minutes, removing the supernatant. Deposits obtained after the supernatant was removed, plus distilled saline $\pm 0.5 \mathrm{ml}$ of distilled saline, were then ready for use.

Drop the API 50CH device with sterile distilled water on each plastic bottom hole, then place the fire kit on the surface, cover with plastic and wait 5 minutes. Prepare the isolate to be tested by planting $100 \mathrm{ml}$ of the prepared isolate into the API 50CH media kit, then vortex. Plant $100 \mathrm{ml}$ of the isolate which has been mixed with an API 50CH media kit into each device kit hole (0 - 50). Incubation at $37^{\circ} \mathrm{C}$ in an anaerobic atmosphere. Then observe it within 24 hours and 48 hours, and compare it to the API standard.

\section{Data analysis}

Data analysis was carried out descriptively based on empirical data obtained and presented through pictures and tables.

\section{III.RESULTS AND ANALYSIS}

\section{Cultivation of BAL Isolate SR 13}

BAL managed to grow in this cultivation. The growth of BAL on the MRS broth media was marked by turbidity in the media.

\section{Confirmation of Isolate BAL SR 13}

According to Rostinawati [5] Gram staining was used to determine the morphology of bacterial cells and to distinguish Gram positive and Gram negative bacteria. Lay [6] states that Gram-positive bacteria in Gram-colored staining are caused by a complex of violetiodine crystalline dyes which are retained even if given acetone alcohol bleaching solution, whereas Gram-negative bacteria are red because the complexes dissolve 
when administering acetone alcoholic soaking solution safranin red color. Color differences in Gram positive and Gram negative bacteria indicate that there are differences in cell wall structure between the two types of bacteria. Gram positive bacteria have cell wall structure with thick peptidoglycan content while Gram negative bacteria have cell wall structure with high lipid content.

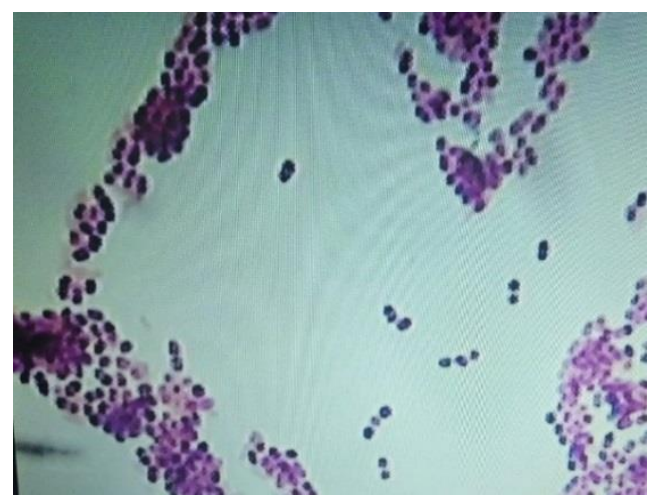

Figure 1. Coloring Results of SR Isolate SR 13. Purple isolates with coccus form.

Gram staining results showed that BAL isolates SR 12 belonged to the group of Gram positive bacteria because they were able to maintain the purple color of crystal violet after being given safranin counter dye, and had the form of cocci cells.

The principle of catalase test is to detect the presence of enzyme catalase in bacteria which is useful in breaking down hydrogen peroxide (H2O2) into 2 molecules of water (H2O) and 1 molecule of oxygen $(\mathrm{O} 2)$. Lactic acid bacteria are a collection of bacteria which mostly show negative catalase properties.

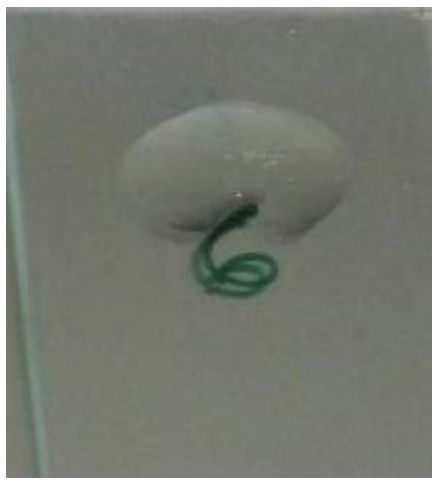

Figure 2. Catalysis of BAL Isolate SR 13. Test results characterized by the absence of gas bubbles.

Catalase test on BAL isolates SR 13 showed negative results because the candidate for the formation of bubbles which indicates oxygen $(\mathrm{O} 2)$ results from the breakdown of hydrogen peroxide ( $\mathrm{H} 2 \mathrm{O} 2)$.

Characterization of SR 13 BAL Isolate 
Based on the growth test at a temperature of $10^{\circ} \mathrm{C}$ that has been done, the results obtained that $\mathrm{BAL}$ isolate $\mathrm{SR}$ 13 was able to grow on MRS broth media incubated at $10^{\circ} \mathrm{C}$. This growth is indicated by turbidity in the media. BAL that can grow at a temperature of $10^{\circ} \mathrm{C}$ is the genera Aerococcus, Enterococcus, Tetragonococcus, Lactobacillus, Pediococcus, Leuconostoc, Oenococcus, and Lactococcus [7].

Based on the growth test on medium with high salt content that has been done, the results showed that BAL isolates SR 13 were not able to grow on $15 \% \mathrm{NaCL}$ media .Based on the growth test at $\mathrm{pH} 9.6$ that has been done, the results obtained that BAL isolate SR 13 was able to grow on MRS broth media incubated at $\mathrm{pH}$ 9.6. This is indicated by the presence of turbidity in the media. The genus Aerococcus, Enterococcus, and Tetragonococcus can grow in alkaline / $\mathrm{pH}$ 9.6. Conventional test results of BAL Isolate SR 13 are presented in table 1

TABLE 1. RESULTS OF CONVENTIONAL BAL TEST ISOLATES SR 13

\begin{tabular}{lc}
\hline & Result \\
\hline Gram Staining & Positive \\
Shape & Coccus \\
Catalase Test & Negative \\
$10^{\circ} \mathrm{C}$ Temperature Test & Positive \\
$15 \% \mathrm{NaCl}$ Test & Negative \\
$9.6 \mathrm{pH}$ Test & Positive \\
\hline Conclusion & Pediococcus/Enterococcus
\end{tabular}

Referring to the identification key to the genus BAL based on the method of Holzapfel and Schilinger [8] and seen from the results of conventional tests, the isolate BAL SR 13 can be identified as thegenus Pediococcus or Enterococcus. The test results need to be resumed usingbiochemical tests in the form of API $50 \mathrm{CH}$ kit test to get more accurate result.
Identification of BAL Isolate SR 13 with API 50 CH Kit

The API kit test was carried out to detect BAL isolates SR 13 by utilizing the properties of lactic acid bacteria which ferment sugar and biochemical characteristics by testing sweets on 50 types of sugar. API $50 \mathrm{CH}$ kit test results are presented in Figure 3 


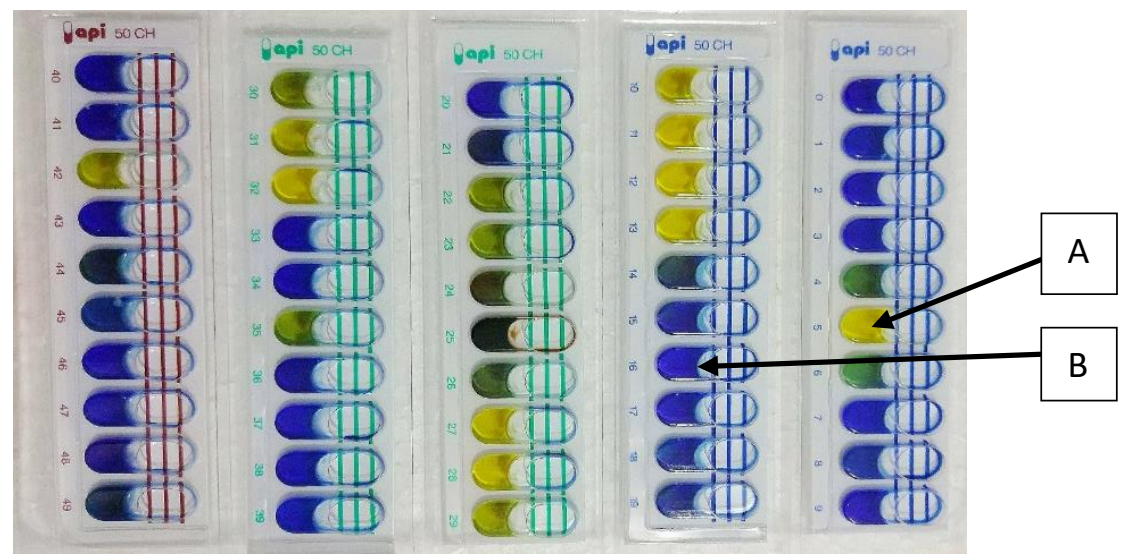

Figure 3. Results of API 50 CH kit tests on BAL isolates SR 13. (A). Positive results (microtube no. 5) are marked by changes in color from blue to yellow; (B). Negative results (micotube no. 16) are marked with no discoloration (blue - blue);

On microtube no. 25 positive results were marked by reddish-black discoloration, this was due to hydrolysis of esculin ferric citrate to esculitin and glucose. Color changes caused by exculitin.

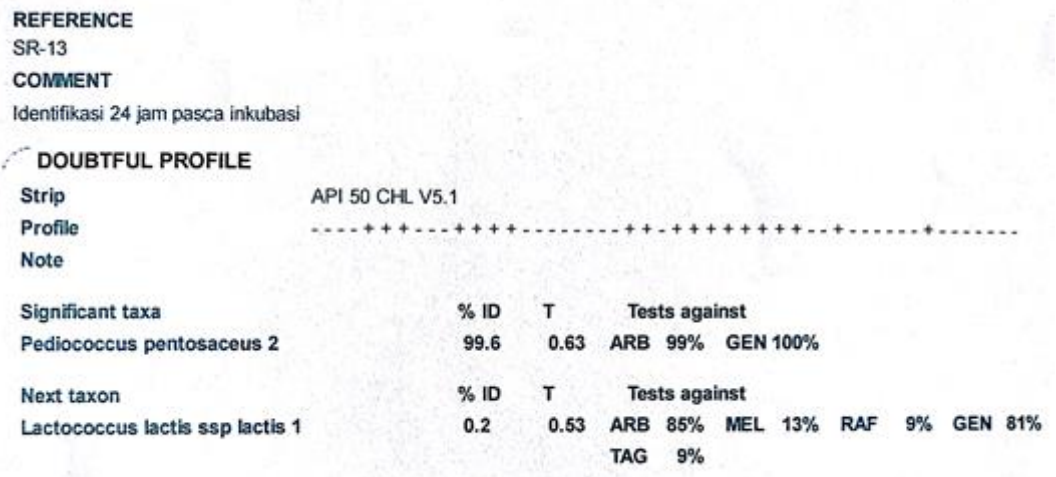

API $50 \mathrm{CH}$ kit test results on the web can be seen in Figure 4.

Figure 4. Test results of the API 50CH kit on the web

Based on the results of the API $50 \mathrm{CH}$ BAL kit test isolates SR 12 were identified as Pediococcus pentosaceus lactic acid bacteria 2. The API $50 \mathrm{CH}$ kit test results were in line with conventional tests.

Pediococcus is a genus of bacteria that includes lactic acid bacteria (BAL) with non-motile characteristics and has a spherical form. These bacterial cells are divided into two fields so that they form pairs, tetrad (arranged four), or larger spherical cells. This bacterium is included in a Gram-positive round shape, especially in pairs. The Pediococcus genus belongs to the facultative anaerobic group and for life requires a nutrient-rich environment and contains growth and sugar factors which can be fermented. These bacteria are homofermentative (produce only lactic 
acid) and cannot use pentose (C5carbohydrate carbohydrate) (Victoria, [9].

Species and strains of this genus differ in tolerance or resistance to oxygen, $\mathrm{pH}$, temperature, antibiotic resistance, and $\mathrm{NaCl}$. Some strains of Pediococcus have been known to have one or more plasmids in various sizes, some of which encode genes for carbohydrate fermentation and bacteriocin production[10].

Most Pediococcus $\mathrm{sp}$ is also capable of fermenting galactose and maltose, although it has been reported that some strains of Pediococcus damnosus, Pediococcus parvulus, and P. claussenii do not have this ability [11]. Sucrose is also fermented by all species except Pediococcus inopinatus, Pediococcus parvulus, Pediococcus pentosaceus, and Pediococcus claussenii. In contrast, rhamnose, melibiose, melezitose, raffinose, inulin, and $\alpha$-methyl glucoside$D$ cannot be fermented by most Pediococcus sp [7].

Since 1985, it has been observed that the ability of Pediococcus sp. to kill spoilage microorganisms and pathogens in meat fermentation due to their ability to produce organic acids. In addition, fermentation with these bacteria also increases food stability during storage and produces products that contain more protein. Although this type is noted as a beer and wine destroyer, this bacteria plays an important role in the fermentation of meat and vegetables [12]. In addition, Pediococcus pentosaceus has the ability to produce antimicrobial agents (bacteriocins) and their use in food preservation [13]

\section{IV.CONCLUSION}

The results of this study indicate that BAL isolates SR 13 from Bali cattle rumen in conventional trials were $\mathrm{BAL}$ of the genus Pediococcus / Enterococcus which was confirmed by the API 50CH kit test as BAL of the genus Pediococcus Pentosaceus 2.

\section{SUGGESTION}

Identification of BAL isolates SR 13 from rumen fluid of Balinese cattle by utilizing physiological and biochemical characteristics still has some disadvantages, namely identification is limited to conventional tests and species identified are limited to the tables provided in the API 50CH kit. So it is advisable to do molecular testing through DNA analysis to the sequencing stage to be more convincing in phylogenesis of isolates SR 13 , so that more accurate identification can be obtained.

\section{REFERENCES}

[1] Widyastuti Y, Sofarianawati E.1999. Karakter Bakteri Asam Laktat Enteroccocus sp. Yang Diisoloasidari Saluran Pencernaan Ternak. Jurnal Mikrobiologi Indonesia. 4(2):50-53

[2] Surono IS. 2004. Probiotik, Susu Fermentasi dan Kesehatan. PT. Tri Cipta Karya. Jakarta.

[3] Jeevaratnam K, Jamuna M, Bawa AS. 2005. Biological preservation of foods-bacteriocins of lactic acid bacteria. Indian journal of biotechnology 4:446-454.

[4] Guntoro S. 2002. Membudidayakan Sapi Bali. Kanisius. Yogyakarta.

[5] Rostinawati, T. 2008. Skrining dan Identifikasi Bakteri Penghasil Enzim Kitinase Dari Air Laut di Perairan Pantai Pondok Bali. 
[6] Penelitian Mandiri. Fakultas Farmasi Universitas Padjadjaran Jatinangor.

[7] Lay, W. B. 1994. AnalisisMikroba di Laboratorium. PT Raja GrafindoPersada, Jakarta.

[8] Lahtinen S, Ouwehand AC, Salminen S, Wright A. 2012. Lactic Acid Bacteria. Microbiological and Functional Aspect Fourth Edition. CRC Press.

[9] Holzapfel WH and Schilinger,U. 1992. The Genus Leuconostoc. In: Balows A, HG Truper, H.G., Harder, W., and Cleifer (eds.) The procaryotes, 2nd editions. Springer, Berlin Heidelberg New York. P:1508-1534

[10] M. Victoria Moreno-Arribas, Carmen Polo, María Carmen Polo (2008). Wine chemistry and biochemistry. Springer
[11] Yiu H. Hui, George G. Khachatourians (1994). Food Biotechnology: Microorganisms. Wiley-Interscience.

[12] Simpson WJ, Taguchi H. 1995. The genus Pediococcus, with notes on the genera Tetragenococcus and Aerococcus. In: The Genera of Lactic Acid Bacteria, Eds. B.J.B. Wood and W.H. Holzapfel, pp. 125-172. Blackie Academic \& Professional, London.

[13] Alcamo, I. E. 2001. Fundamentals of Microbiology. Jones and Bartlett. Boston.

[14] Osmanagaoglu, O; Kiran, F and Nes, Ingolf F. 2011. A Probiotic Bacterium, Pediococcus pentosaceus OZF Isolated from Human Breast Milk Produces Pediocin AcH/PA-1. African Journal of Biotechnology. Vol. 10(11): 2070-2079 